\title{
Implementasi User Satisfaction Model Dalam Mengukur Kualitas Website
}

\author{
Mardiana \\ Sistem Informasi, STMIK PalComTech, Palembang \\ E-Mail: mardiana@palcomtech.ac.id
}

\begin{abstract}
ABSTRAK
PT. Etos Indonusa adalah salah satu perusahaan di Palembang yang bergerak di bidang pembasmian hama. PT. Etos Indonusa sebagai salah satu perusahaan di Palembang yang bergerak di bidang pembasmian hama memiliki website yang difungsikan sebagai media informasi sekaligus promosi kepada para pelanggan baik digunakan oleh pihak internal maupun eksternal perusahaan. Penelitian ini bertujuan untuk mengukur tingkat kepuasan pengguna dalam penerapan website PT. Etos Indonusa sehingga diketahui berapa besar kepuasan user terhadap kualitas website yang digunakan. Penelitian ini menggunakan metode user satisfaction dari Green Pearson dengan empat variabel; easy of use, customization, download delay dan content. Populasi dalam penelitian ini sebanyak 50 mitra dengan menggunakan teknik sampling sensus sehingga semua populasi dapat dijadikan sampel penelitian. Metode pengujian data menggunakan uji validitas dan reliabilitas dimana hasil penelitian ini akan menunjukkan nilai perhitungan yang akan diinterpretasikan. Berdasarkan hasil penelitian pada variabel content memperoleh nilai terendah di rata-rata $60 \%$ dengan interpretasi cukup. Hal ini menunjukkan bahwa website PT. Etos Indonusa memerlukan perhatian lebih dari sisi konten materi yang perlu diperbaiki, ditambah dan diperbaharui sesuai dengan kebutuhan pengguna.
\end{abstract}

Kata Kunci: User Satisfaction, Kualitas, Website, Pengukuran.

\section{ABSTRACT}

PT. Etos Indonusa as one of the company in Palembang engaged in pest eradication which has a website that functions as a media of information as well as promotion to customers both used by internal and external parties. This study aims to measure the level of user satisfaction in implementing the website of PT. Etos Indonusa so that it is known how much user satisfaction with the quality of the website used. This study uses the user satisfaction method of Green Pearson with four variables; easy of use, customization, download delay and content. The population in this study as many as 50 partners using census sampling techniques so that all populations can be used as research samples. The data testing method uses a validity and reliability test where the results of this study will show the calculated value to be interpreted. Based on research results, the content variable gets the lowest value at an average of $60 \%$ with enough interpretation. This shows that the website of PT. Etos Indonusa requires more attention in terms of material content that needs to be improved, added and updated according to user needs.

Keywords: User Satisfaction, Quality, Website, Measurement.

Author Korespondensi (Mardiana)

Email :mardiana@palcomtech.ac.id

\section{PENDAHULUAN}

Website merupakan keseluruhan halaman halaman web yang terdapat dari sebuah domain yang mengandung informasi [1]. Website dapat menjadi alat bantu yang menghubungkan perusahaan dengan pelanggan. Banyak perusahaan menggunakan website untuk menginformasikan tentang perusahaan mereka mulai dari profil sampai dengan produk atau jasa yang mereka tawarkan.

PT. Etos Indonusa sebagai salah satu perusahaan di Palembang yang bergerak di bidang pembasmian hama. PT. Etos Indonusa memiliki website yang digunakan oleh pihak internal dan eksternal perusahaan yang dapat diakses melalui alamat https://www.etos.co.id. Website ini difungsikan sebagai media informasi sekaligus promosi kepada para pelanggan. Adapun fitur yang dimiliki website ini adalah dashboard yang difungsikan sebagai halaman utama saat mengakses website, about us yang berisi informasi profil perusahaan, services berisi pelayanan yang ditujukan kepada pelanggan, news berisi info-info mulai dari promosi, tips sampai ke berita terkini, carier berisi tugas fungsional staf perusahaan dan informasi 
lowongan, contact berisi alamat dan nomor perusahaan yang bisa dihubungi, dan fitur login untuk akses karyawan dalam meng-input data transaksi. Sampai saat ini website PT. Etos Indonusa belum dilakukan aktivitas pengukuran terutama dalam hal kepuasan pengguna. Hal ini menyebabkan tidak adanya pembaharuan website yang dilakukan oleh perusahaan sehingga fitur-fitur dalam website terkesan statis.

Pengukuran perangkat lunak merupakan hal yang paling penting dalam kegiatan perekayasaan (engineering). Aktivitas ini akan menjadi hal yang penting dalam proses pengembangan sistem dan dapat dijadikan sebagai keputusan apakah perlu adanya perbaikan dari sistem yang telah dikembangkan.

User Satisfaction model diperkenalkan pertama kali oleh Green dan Pearson pada tahun 2009 [2]. Kepuasan pengguna adalah keseluruhan evaluasi dari pengalaman pengguna dalam menggunakan sistem informasi dan dampak potensial dari sistem informasi [3]. Kepuasan pengguna juga merupakan perasaan menyenangkan atau tidaknya dalam menggunakan sistem informasi terhadap keseluruhan manfaat yang diinginkan seseorang dimana perasaan itu diperoleh dari hubungan manusia dengan sistem informasi [4]. Green dan Pearson menyatakan tingkat kepuasaan pengguna pada suatu perangkat dapat diukur dengan menggunakan model tingkat kepuasaan dengan empat (4) variabel yang terdiri dari: Kemudahan (Easy of Use / Ease of Navigation), Personalisasi (Customization), Kecepatan akses pada aplikasi (Download Delay), dan Penyajian Informasi (Content) [5].

Penelitian ini bertujuan untuk mengukur tingkat kepuasan pengguna dalam penerapan website PT. Etos Indonusa sehingga diketahui berapa besar kepuasan user terhadap kualitas website yang digunakan. Dalam mengukur tingkat kepuasan pengguna untuk melihat kualitas website, metode user satisfaction dari Green Pearson dirasa tepat karena terdiri dari 4 variabel yang tidak hanya fokus terhadap kepuasan pengguna namun juga lebih menekankan pada sisi kualitas website.

Penelitian yang berjudul Pengukuran Kepuasan Pengguna Situs Web dengan Metode End User Computing Satisfaction (EUCS) yang terdiri dari variabel content, accuracy, format, ease of use dan timeliness yang dirumuskan oleh Doll et al [6]. Tujuannya adalah mengukur sejauh mana kepuasan pengguna terhadap situs web Universal University yang akan dijadikan sebagai bahan evaluasi sistem [7].

Penelitian berikutnya berjudul Pengaruh Kualitas Sistem, Kualitas Informasi, dan Kualitas Layanan Terhadap Kepuasan Pengguna Sistem E-Learning. Tujuannya adalah untuk menganalisa pengaruh kualitas sistem, kualitas informasi, kualitas layanan terhadap kepuasan pengguna sistem e-learning. Dari hasil analisa menunjukkan bahwa terdapat pengaruh signifikan dari semua variabel dalam penerapan e-learning [8].

Penelitian selanjutnya membahas tentang Pengukuran Tingkat Kepuasan Pengguna Sistem Informasi DJP Online Pelaporan SPT Pajak menggunakan PIECES framework. Tahapan dalam penelitian ini yaitu merumuskan masalah, merumuskan hipotesa, mengumpulkan data, pengolahan data dan hasil penelitian. Hasil dari penelitian ini berupa evaluasi dan pengembangan sistem informasi DJP Online berdasarkan tingkat kepuasan pengguna [9].

\section{METODOLOGI}

Metodologi penelitian merujuk pada langkahlangkah berikut:

1. Mengumpulkan data-data terkait penggunaan website PT. Etos Indonusa yaitu dengan melakukan observasi, wawancara dan dokumentasi.

2. Mengumpulkan studi pustaka terkait user satisfaction dari Green \& Pearson.

3. Merumuskan metode user satisfaction kedalam kuesioner.

4. Menyebarkan kuesioner kepada mitra PT. Etos Indonusa dan mengumpulkan hasilnya.

5. Melakukan uji validitas dan reliabilitas.

6. Menginterpretasikan hasil pengukuran.

7. Membuat hasil kesimpulan penelitian dan memberikan saran perbaikan.

Penelitian ini bersifat deskriptif dengan pendekatan kuantitatif. Menurut Lehmann, penelitian deskriptif kuantitatif adalah salah satu jenis penelitian yang bertujuan mendeskripsikan secara sistematis, faktual, dan akurat mengenai fakta dan sifat populasi tertentu, atau mencoba menggambarkan fenomena secara detail [10]. Jenis data penelitian ini berupa data primer dan sekunder yang diperoleh dari PT. Etos Indonusa. Skala pengukuran menggunakan skala likert 
dengan 4 alternatif jawaban. Penelitian ini menjadikan mitra atau pelanggan sebagai populasi sebanyak 50 mitra dengan menggunakan teknik sampling sensus sehingga semua populasi dapat dijadikan sampel penelitian. Metode pengujian data menggunakan uji validitas dan reliabilitas dimana hasil penelitian ini akan menunjukkan nilai perhitungan yang akan diinterpretasikan.

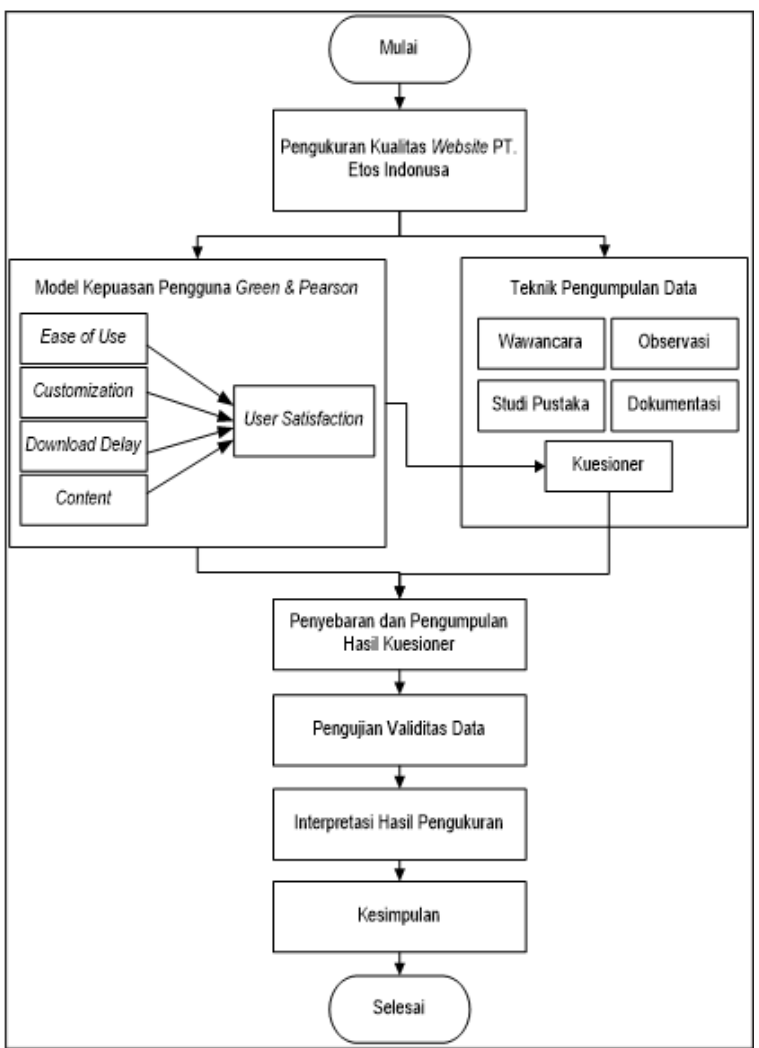

Gambar 1. Alur Penelitian

\section{HASIL DAN PEMBAHASAN}

Website yang dimiliki oleh PT. Etos Indonusa dapat diakses melalui alamat https://www.etos.co.id. Adapun fitur yang dimiliki website ini adalah dashboard yang difungsikan sebagai halaman utama saat mengakses website, about us yang berisi informasi profil perusahaan, services berisi pelayanan yang ditujukan kepada pelanggan, news berisi info-info mulai dari promosi, tips sampai ke berita terkini, carier berisi tugas fungsional staf perusahaan dan informasi lowongan, contact berisi alamat dan nomor perusahaan yang bisa dihubungi, dan fitur login untuk akses karyawan dalam meng-input data transaksi. Tampilan website PT. Etos Indonusa dapat dilihat dari gambar - gambar berikut:

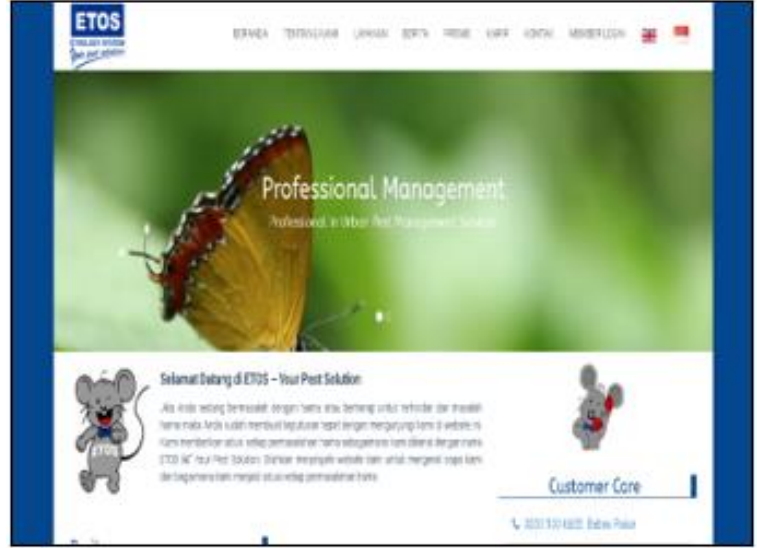

Gambar 2. Tampilan Dashboard

Gambar 2 merupakan tampilan awal saat pengunjung mengakses website PT. Etos Indonusa. Pada tampilan ini pengunjung diberikan kemudahan jelajah website dimana posisi menu berada pada bagian paling atas dan jelas.

\subsection{Karakteristik Responden}

Analisis deskriptif dalam penelitian ini berfungsi untuk melihat karakter dari responden [11]. Karakteristik responden terdiri dari data gender, umur dan status pendidikan.

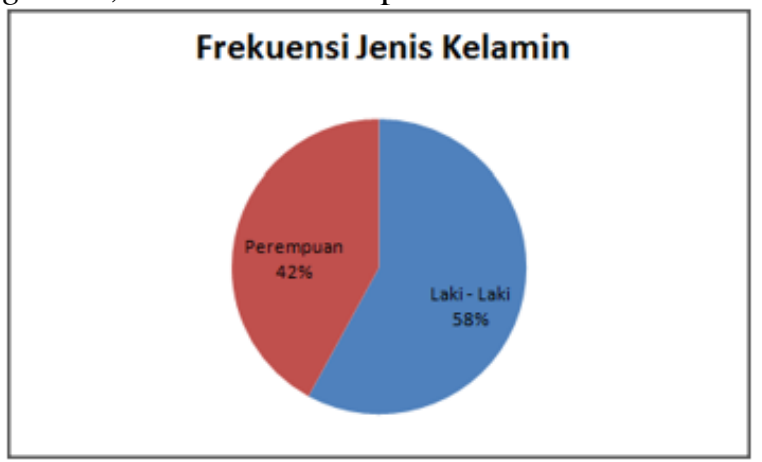

Gambar 3. Gender Responden

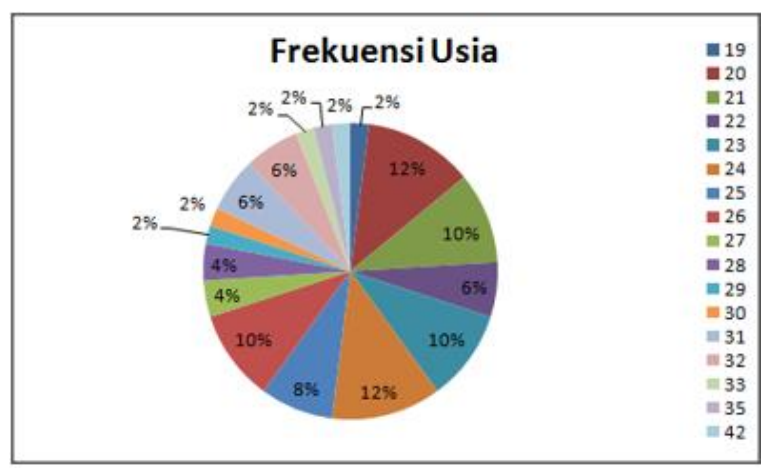

Gambar 4. Umur Responden 


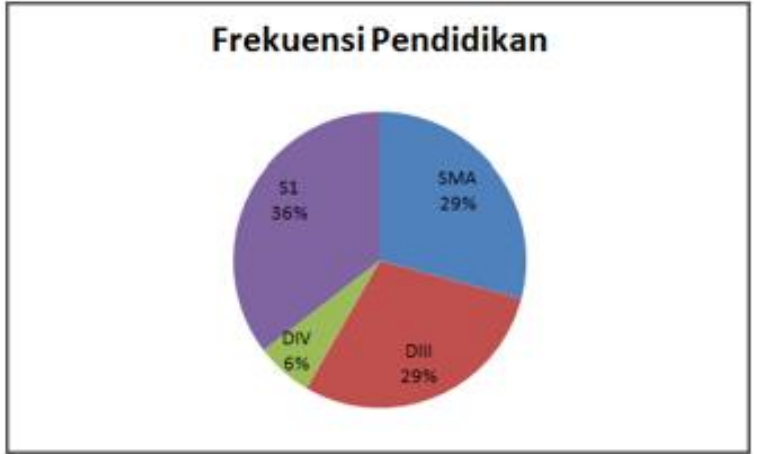

Gambar 5. Status Pendidikan Responden

Dari data karakteristik responden diatas dapat diketahui bahwa distribusi terbesar dalam penelitian ini berasal dari responden dengan jenis kelamin laki-laki berusia 20 tahun dan pendidikan Diploma. Ini menunjukkan bahwa responden dengan rentang umur yang masih muda dan berpendidikan pasti dapat menggunakan website ini dengan baik.

\subsection{Pengujian Validitas}

Uji validitas merupakan suatu teknik yang digunakan untuk mengetahui apakah instrument kuesioner dianggap valid atau tidak. Kuesioner dapat dikatakan valid apabila nilai $r$ hitung lebih besar dari $r$ tabel. Dari pengolahan data menggunakan aplikasi SPSS diperoleh nilai Rtabel sebesar 0,24. Dalam menentukan nilai Rtabel menggunakan rumus perhitungan t_0.05/SQRT(df+t_0.05**2) [12].

Tabel 1. Hasil Pengujian Validitas

\begin{tabular}{|c|c|c|}
\hline Indikator & $\begin{array}{c}\text { Corrected Item- } \\
\text { Total Correlation }\end{array}$ & Keterangan \\
\hline $\mathrm{X} 1$ & 0,727 & Valid \\
\hline $\mathrm{X} 2$ & 0,753 & Valid \\
\hline $\mathrm{X} 3$ & 0,870 & Valid \\
\hline $\mathrm{X} 4$ & 0,811 & Valid \\
\hline $\mathrm{X} 5$ & 0,749 & Valid \\
\hline $\mathrm{X} 6$ & 0,636 & Valid \\
\hline $\mathrm{X} 7$ & 0,887 & Valid \\
\hline $\mathrm{X} 8$ & 0,886 & Valid \\
\hline
\end{tabular}

\begin{tabular}{|c|c|c|}
\hline Indikator & $\begin{array}{c}\text { Corrected Item- } \\
\text { Total Correlation }\end{array}$ & Keterangan \\
\hline $\mathrm{X} 9$ & 0,435 & Valid \\
\hline $\mathrm{X} 10$ & 0,671 & Valid \\
\hline $\mathrm{X} 11$ & 0,769 & Valid \\
\hline $\mathrm{X} 12$ & 0,738 & Valid \\
\hline $\mathrm{X} 13$ & 0,731 & Valid \\
\hline $\mathrm{X} 14$ & 0,588 & Valid \\
\hline $\mathrm{X} 15$ & 0,685 & Valid \\
\hline $\mathrm{X} 16$ & 0,682 & Valid \\
\hline $\mathrm{X} 17$ & 0,797 & Valid \\
\hline $\mathrm{X} 18$ & 0,648 & Valid \\
\hline
\end{tabular}

Tabel 1 menunjukkan bahwa semua indikator dalam kuesioner bernilai valid. Hal ini terlihat dari nilai corrected item-total correlation sebagai $r$ hitung mulai dari X1 sampai X18 lebih besar dari $r$ tabel 0,24 .

\subsection{Pengujian Reliabilitas}

Uji reliabilitas merupakan suatu teknik yang digunakan untuk mengukur konsisten atau tidaknya suatu data. Uji reliabilitas menggunakan metode Cronbach Alpha. Instrumen dapat dikatakan handal (reliable) bila memiliki koefisien Cronbach Alpha $>0,70$ (Nunnally) [13].

Tabel 2. Hasil Pengujian Reliabilitas

\begin{tabular}{|c|c|c|}
\hline Variabel & $\begin{array}{c}\text { Cronbach's } \\
\text { Alpha }\end{array}$ & Ket \\
\hline Ease of use & 0,802 & Reliabel \\
\hline Customization & 0,784 & Reliabel \\
\hline Download delay & 0,763 & Reliabel \\
\hline Content & 0,780 & Reliabel \\
\hline
\end{tabular}

\subsection{Interpretasi Hasil Pengukuran}

Instrumen kuesioner yang memenuhi syarat setelah melalui pengujian validitas dan reliabilitas akan dilanjutkan ke tahap perhitungan interpretasi.

Tabel 3. Interpretasi Hasil Pengukuran 


\begin{tabular}{|c|c|c|c|}
\hline Indikator & Kode & Nilai & $\begin{array}{l}\text { Inter- } \\
\text { pretasi }\end{array}$ \\
\hline \multicolumn{4}{|c|}{ Ease Of Use } \\
\hline $\begin{array}{l}\text { Pengguna mudah untuk } \\
\text { mengakses web }\end{array}$ & $\mathrm{X} 1$ & $74 \%$ & Kuat \\
\hline $\begin{array}{l}\text { Pengguna cukup sering } \\
\text { mengakses } w e b\end{array}$ & $\mathrm{X} 2$ & $70,5 \%$ & Kuat \\
\hline $\begin{array}{l}\text { Pengguna mudah } \\
\text { mengakses menu \& } \\
\text { link dalam web }\end{array}$ & $\mathrm{X} 3$ & $70,5 \%$ & Kuat \\
\hline $\begin{array}{l}\text { Pengguna mudah } \\
\text { melakukan pencarian } \\
\text { informasi yang } \\
\text { dibutuhkan dalam web }\end{array}$ & $\mathrm{X} 4$ & $69,5 \%$ & Kuat \\
\hline $\begin{array}{l}\text { Tampilan web ini dapat } \\
\text { menyesuaikan saat } \\
\text { diakses melalui mobile } \\
\text { phone maupun } \\
\text { komputer/personal } \\
\text { computer }\end{array}$ & $\mathrm{X} 5$ & $71,5 \%$ & Kuat \\
\hline \multicolumn{4}{|c|}{ Customization } \\
\hline $\begin{array}{l}\text { Tampilan web ini mudah } \\
\text { dikenali }\end{array}$ & $\mathrm{X} 6$ & $63 \%$ & Kuat \\
\hline $\begin{array}{l}\text { Teknik pewarnaan dalam } \\
\text { web ini cukup menarik } \\
\text { dan tidak membosankan }\end{array}$ & $\mathrm{X} 7$ & $62,5 \%$ & Kuat \\
\hline $\begin{array}{l}\text { Pembagian posisi } \\
\text { informasi yang disajikan } \\
\text { didalam web mudah } \\
\text { dikenali }\end{array}$ & $\mathrm{X} 8$ & $62 \%$ & Kuat \\
\hline $\begin{array}{l}\text { Teks yang ditampilkan } \\
\text { dalam web ini mudah } \\
\text { dibaca dengan jelas }\end{array}$ & $\mathrm{X} 9$ & $86,5 \%$ & Kuat \\
\hline \multicolumn{4}{|c|}{ Download Delay } \\
\hline $\begin{array}{l}\text { Informasi yang } \\
\text { dibutuhkan dari web ini } \\
\text { mudah untuk didownload }\end{array}$ & $\mathrm{X} 10$ & $76,5 \%$ & Kuat \\
\hline $\begin{array}{l}\text { Pengguna tidak } \\
\text { membutuhkan waktu } \\
\text { lama saat mendownload } \\
\text { informasi yang ada pada } \\
\text { web }\end{array}$ & $\mathrm{X} 11$ & $70,5 \%$ & Kuat \\
\hline $\begin{array}{l}\text { Setiap halaman dalam } \\
\text { web ini ditampilkan } \\
\text { dengan cepat setelah } \\
\text { mengklik link yang ada }\end{array}$ & $\mathrm{X} 12$ & $74 \%$ & Kuat \\
\hline $\begin{array}{l}\text { Pengguna mudah untuk } \\
\text { mengakses informasi } \\
\text { pada setiap halaman yang } \\
\text { ada dalam web }\end{array}$ & $\mathrm{X} 13$ & $70,5 \%$ & Kuat \\
\hline $\begin{array}{l}\text { Secara keseluruhan } \\
\text { komponen web ini tidak } \\
\text { mengalami eror }\end{array}$ & $\mathrm{X} 14$ & $74 \%$ & Kuat \\
\hline
\end{tabular}

\begin{tabular}{|c|c|c|c|}
\hline \multicolumn{4}{|c|}{ Content } \\
\hline $\begin{array}{l}\text { Informasi yang disajikan } \\
\text { dalam web ini sesuai } \\
\text { dengan kebutuhan } \\
\text { pengguna }\end{array}$ & $\mathrm{X} 15$ & $66,5 \%$ & Kuat \\
\hline $\begin{array}{l}\text { Keberagaman informasi } \\
\text { yang disajikan dalam web } \\
\text { ini cukup menarik }\end{array}$ & $\mathrm{X} 16$ & $69,5 \%$ & Kuat \\
\hline $\begin{array}{l}\text { Gambar yang } \\
\text { ditampilkan dalam web } \\
\text { ini dapat dilihat dengan } \\
\text { jelas }\end{array}$ & $\mathrm{X} 17$ & $66,5 \%$ & Kuat \\
\hline $\begin{array}{l}\text { Informasi yang disajikan } \\
\text { up to date }\end{array}$ & $\mathrm{X} 18$ & $60 \%$ & Cukup \\
\hline
\end{tabular}

Adapun kesimpulan dari hasil pengolahan data diatas adalah:

a. Untuk indikator kemudahan akses web (ease of use) memperoleh nilai $74 \%$ dengan interpretasi Kuat. Ini menunjukkan bahwa website ini memberikan kemudahan bagi user dalam menggunakannya.

b. Untuk indikator teks jelas dan mudah dibaca (customization) memperoleh nilai 86,5\% dengan interpretasi Kuat. Ini menunjukkan bahwa website ini memiliki tampilan teks yang mudah terbaca dan jelas.

c. Untuk indikator informasi mudah didownload (download delay) memperoleh nilai $76,5 \%$ dengan interpretasi Kuat. Ini menunjukkan bahwa website ini memberikan informasi yang dapat di-download dengan mudah.

d. Untuk indikator informasi yang up to date (content) memperoleh nilai $60 \%$ dengan interpretasi Cukup. Ini menunjukkan bahwa website ini memerlukan perhatian lebih dari sisi konten materi yang perlu diperbaiki, ditambah dan diperbaharui. 


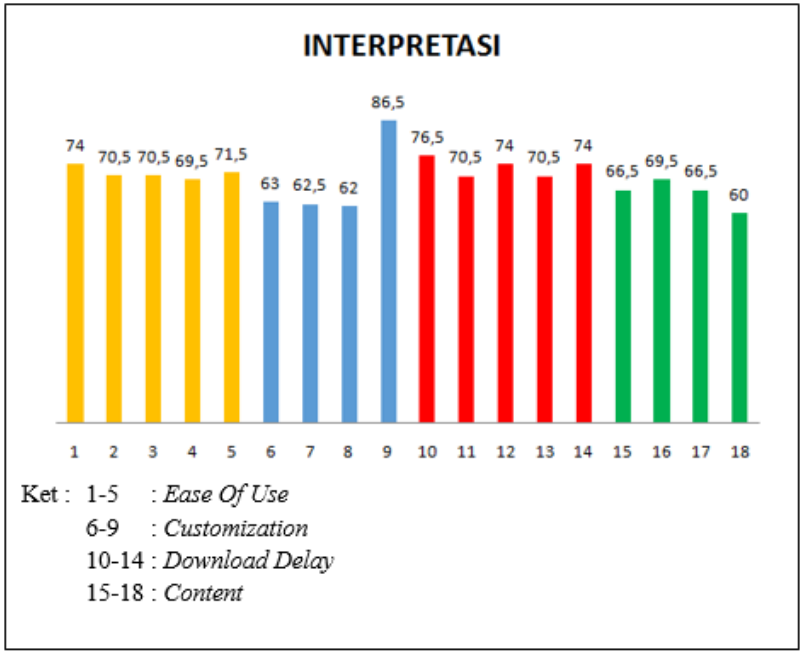

Gambar 8. Interpretasi Hasil Pengukuran

\section{SIMPULAN DAN SARAN}

Dari hasil implementasi metode user satisfaction Green \& Pearson menunjukkan bahwa pada variabel easy of use, customization dan download delay memperoleh nilai baik dengan interpretasi kuat. Sedangkan pada variabel content memperoleh nilai terendah di rata-rata $60 \%$ dengan interpretasi cukup. Hal ini menunjukkan bahwa website PT. Etos Indonusa memerlukan perhatian lebih dari sisi konten materi yang perlu diperbaiki, ditambah dan diperbaharui sesuai dengan kebutuhan pengguna.

Adapun saran untuk upaya perbaikan lanjut adalah sebagai berikut:

1. Memastikan informasi yang disajikan dalam website sesuai dengan kebutuhan pengguna.

2. Menyajikan keberagaman informasi yang menarik.

3. Memastikan informasi yang diterima pelanggan selalu up to date.

4. Menambah fitur chat online yang dapat membantu komunikasi pelanggan dan perusahaan

5. Penelitian lebih lanjut dapat dikembangkan tidak hanya pada user satisfaction saja, tapi juga pada aspek usability sehingga hasil penelitian akan lebih akurat.

\section{UCAPAN TERIMA KASIH}

Ucapan terimakasih penulis sampaikan kepada STMIK PalComTech yang telah memberikan kontribusi terhadap penelitian ini, penulis juga bertetimakasih kepada mahasiswa yang telah membantu penelitian ini.

\section{REFERENSI}

[1] Yuhefizar, 2013, "Cara Mudah \& Murah Membangun \& Mengelola Website", Yogyakarta: Graha Ilmu.

[2] Amri, Z., Uska, M. Z. dan Dwiarianti. B. D., 2018 "Analisis Usability Website Universitas Hamzanwadi Terhadap Kepuasan Pengguna Dengan Menggunakan User Satisfaction Model", EDUMATIC J. Pendidik. Inform., Vol. 2, No. 2, pp. 15-23.

[3] Krisbiantoro, D., Suyanto. M. dan Taufiqluthfi. E., 2015, “Evaluasi Keberhasilan Implementasi Sistem Informasi Dengan Pendekatan Hot Fit Model (Studi Kasus: Perpustakaan STMIK AMIKOM Purwokerto)", Konf. Nas. Sist. Inform., pp. 9-10.

[4] Noviandini, N. C., 2012, "Pengaruh Persepsi Kebermanfaatan, Persepsi Kemudahan Penggunaan, Dan Kepuasan Wajib Pajak Terhadap Penggunaan EFiling Bagi Wajib Pajak Di Yogyakarta", Nominal, Barom. Ris. Akunt. dan Manaj., Vol. 1, No. 1, pp. 15-22.

[5] Mardiana dan Hartati, E., 2019 "Analisis Pengukuran Tingkat Kepuasan Pengguna Terhadap Penerapan Aplikasi SISKEUDES Pada Kabupaten Banyuasin Sumatera Selatan", MATRIK J. Manajemen, Tek. Inform. dan Rekayasa Komput., vol. 19, no. 1, pp. 93-99, 2019.

[6] W. J. Doll and G. Torkzadeh, 1998, "The Measurement of End - User Computing Satisfaction", Vol. 12, No. 2.

[7] Fitriansyah, A., dan Harris, I., 2018, "Pengukuran Kepuasan Pengguna Situs Web Dengan Metode End User Computing Satisfaction (EUCS)", Query 
J. Sist. Inf., Vol. 2, No. 1, pp. 1-8.

[8] Pawirosumarto, S., Katidjan, P.S., dan Mulyanto, A.D., 2016, "Pengaruh Kualitas Sistem, Kualitas Informasi, Dan Kualitas Layanan Terhadap Kepuasan Pengguna Sistem E-learning”, Mix J. Ilm. Manaj., Vol. 6, No. 3.

[9] Supriyatna, A., dan Maria, V., 2017 "Pengukuran Tingkat Kepuasan Pengguna Sistem Informasi Djp Online Pelaporan Spt Pajak", Pros. SNATIF, ISBN: 978-602-1180-50-1, pp. 147-154.

[10] Yusuf, M., 2017, "Metode Penelitian: Kuantitatif, Kualitatif, dan Penelitian Gabungan", Edisi Pertama, Jakarta: Kencana.

[11] Handayani, F. S., 2014, "Pengukuran Tingkat Kepuasan Pengguna Terhadap Web Student Portal Palcomtech", Vol. 4, No. 1, pp. 307-319.

[12] Sudaryono, 2012, "Statistika Probabilitas Teori \& Aplikasi", Yogyakarta: Andi.

[13] Ghozali, 2013, "Aplikasi Analisis Multivariate dengan Program IBM SPSS 21", Semarang: Universitas Diponegoro. 